\title{
Co-Circulation of Multiple Serotypes of Bluetongue Virus in Zambia
}

\author{
Herman M. Chambaro 1,2,3,* Michihito Sasaki ${ }^{1}$ (D), Edgar Simulundu 4,5,*(D), Isaac Silwamba ${ }^{4}$, \\ Yona Sinkala ${ }^{3}$, Gabriel Gonzalez ${ }^{6}$ (D), David Squarre ${ }^{7,8}$, Paul Fandamu ${ }^{3}$, Caesar H. Lubaba ${ }^{3}$, \\ Musso Munyeme ${ }^{4}$, Alikhadio Maseko ${ }^{3}$, Choopa Chimvwele $^{3}$, Liywalii Mataa ${ }^{3}$, \\ Lynnfield E. Mooya 2,3, Andrew N. Mukubesa ${ }^{4}$, Hayato Harima ${ }^{1}$, Kenny L. Samui ${ }^{4}$, \\ Hetron M. Munang'andu ${ }^{9}$ (D, Martin Simuunza ${ }^{4}$, King S. Nalubamba ${ }^{4}$, Yongjin Qiu ${ }^{10}$, \\ Michael J. Carr ${ }^{6,11} \mathbb{D}^{\mathbb{D}}$, William W. Hall ${ }^{6,11,12}$, Yuki Eshita ${ }^{10}$, Hirofumi Sawa ${ }^{1,11,12}$ and \\ Yasuko Orba $1,11, *$ (D)
}

1 Research Center for Zoonosis Control, Hokkaido University, Sapporo 001-0020, Japan; m-sasaki@czc.hokudai.ac.jp (M.S.); harima@czc.hokudai.ac.jp (H.H.); h-sawa@czc.hokudai.ac.jp (H.S.)

2 Virology Unit, Central Veterinary Research Institute, Lusaka 10101, Zambia; emmamooya@yahoo.com

3 Ministry of Fisheries and Livestock, Lusaka 10101, Zambia; sinkalay@yahoo.co.uk (Y.S.); pfandamu@gmail.com (P.F.); caesar.lubaba@gmail.com (C.H.L.); alikhadio21@yahoo.co.uk (A.M.); chimvwele@yahoo.co.uk (C.C.); lmataa_nmataa@yahoo.com (L.M.)

4 School of Veterinary Medicine, The University of Zambia, Lusaka 10101, Zambia; isaacsilwambak@gmail.com (I.S.); mussomunyeme@gmail.com (M.M.); mukubesaandrew@gmail.com (A.N.M.); kennysamui@yahoo.com (K.L.S.); martin.simuunza@unza.zm (M.S.); king.nalubamba@unza.zm (K.S.N.)

5 Macha Research Trust, Choma 10101, Zambia

6 National Virus Reference Laboratory, School of Medicine, Dublin DO4V1W8, Ireland; gabo.hokudai@gmail.com (G.G.); michael.carr@ucd.ie (M.J.C.); william.hall@ucd.ie (W.W.H.)

7 The University of Edinburgh, Edinburgh EH25 9RG, Scotland, UK; davidsquarre@yahoo.co.uk

8 Department of National Parks and Wildlife, Chilanga 10101, Zambia

9 Faculty of Veterinary Medicine and Biosciences, Norwegian University of Life Sciences, 0454 Oslo, Norway; hetroney.mweemba.munangandu@nmbu.no

10 Hokudai Center for Zoonosis Control in Zambia, School of Veterinary Medicine, University of Zambia, Lusaka 10101, Zambia; yongjin_qiu@czc.hokudai.ac.jp (Y.Q.); yeshita@czc.hokudai.ac.jp (Y.E.)

11 International Collaboration Unit, Research Center for Zoonosis Control, Hokkaido University, Sapporo 001-0020, Japan

12 Global Virus Network, Baltimore, MD 21201, USA

* Correspondence: hermcham@gmail.com (H.M.C.); esikabala@yahoo.com (E.S.); orbay@czc.hokudai.ac.jp (Y.O.); Tel.: +81-80-1375-4174 (H.M.C.); +26-09-7746-9479 (E.S.); +81-11-706-5185 (Y.O.)

Received: 12 August 2020; Accepted: 28 August 2020; Published: 31 August 2020

\begin{abstract}
Bluetongue (BT) is an arthropod-borne viral disease of ruminants with serious trade and socio-economic implications. Although the disease has been reported in a number of countries in sub-Saharan Africa, there is currently no information on circulating serotypes and disease distribution in Zambia. Following surveillance for BT in domestic and wild ruminants in Zambia, BT virus (BTV) nucleic acid and antibodies were detected in eight of the 10 provinces of the country. About $40 \%$ $(87 / 215)$ of pooled blood samples from cattle and goats were positive for BTV nucleic acid, while one hartebeest pool (1/43) was positive among wildlife samples. Sequence analysis of segment 2 revealed presence of serotypes 3, 5, 7, 12 and 15, with five nucleotypes (B, E, F, G and J) being identified. Segment 10 phylogeny showed Zambian BTV sequences clustering with Western topotype strains from South Africa, intimating likely transboundary spread of BTV in Southern Africa. Interestingly, two Zambian viruses and one isolate from Israel formed a novel clade, which we designated as Western topotype 4 . The high seroprevalence (96.2\%) in cattle from Lusaka and Central provinces
\end{abstract}


and co-circulation of multiple serotypes showed that BT is widespread, underscoring the need for prevention and control strategies.

Keywords: Reoviridae; bluetongue; bluetongue virus; serotypes; topotypes; sero-surveillance; wild ruminants; domestic ruminants; Zambia

\section{Introduction}

Bluetongue (BT) is a non-contagious, but infectious notifiable arthropod-borne viral disease affecting wild and domestic ruminants, camelids and occasionally large carnivores [1,2]. It is caused by the BT virus (BTV), a member of the family Reoviridae, genus Orbivirus. Although sheep and white-tailed deer are highly susceptible to BTV infection, cattle and goats remain largely asymptomatic [3]. Some BTV strains, such as the virulent serotype 8 , are known to cause clinical disease in cattle $[4,5]$. Asymptomatic cattle with prolonged viremia are considered to play an important role in the epidemiology of BT [6].

BTV possesses a double-stranded RNA genome consisting of 10 segments that encode 7 structural (VP1-VP7) and 5 non-structural proteins (NS1, NS2, NS3/NS3a, NS4 and NS5) which are packaged in a three-layered icosahedral protein capsid [7-9]. The outer capsid layer is composed of VP2 and VP5 proteins, encoded by genome segments 2 and 6, respectively. The VP2 and VP5 proteins induce neutralizing antibodies with the former being the major determinant of virus serotype [7]. To date, 28 BTV serotypes have been identified based on serum neutralization assays and/or nucleotide sequence analysis of segment 2 gene [10-12]. Additionally, segment 2 and 6 of different BTV strains can be classified into distinct nucleotypes, of which, 12 segment 2 (A to L) and 10 segment 6 (A to J) nucleotypes have been reported thus far [13-15]. Sequence analysis of other genome segments, such as segment 10 and 7, allows the assignment of BTV strains into either Western or Eastern topotypes, which can be further divided into minor subgroups that reflect their geographical origins [15]. Due to the high genetic diversity of segment 2, there is phylogenetic incongruency between segment 2 and 10 .

BTV is transmitted primarily by a few species of adult female Culicoides midges. In Africa, Culicoides imicola and Culicoides bolitinos are the principal vectors [16,17]. Even though BT is generally considered endemic to Africa, there is a paucity of information on its occurrence in most countries. Usually, BT outbreaks coincide with periods of high rainfall [18]. In North and East Africa, BT outbreaks involving cattle, sheep and goats have been reported in Egypt, Algeria, Tunisia and Kenya (https: //www.oie.int/wahis). In Southern Africa, outbreaks in sheep and goats have been reported in Botswana, Lesotho, Madagascar, Namibia, South Africa and Zimbabwe (https://www.oie.int/wahis). However, in Southern Africa, information on circulating serotypes is only available for South Africa (serotypes 1 to 24) and Malawi (serotypes 1, 2, 3, 5, 8, 10, 15, 20, 21 and 22) [18,19]. In Zambia, apart from limited serological evidence of BT in domestic and wild ruminants conducted over three decades ago, there is no information on the distribution of the disease and circulating serotypes [20-22]. Similarly, there is very little information on the ecology and distribution of Culicoides midges in Zambia [23].

Zambia is divided into 10 administrative provinces and 117 districts. The country is landlocked and shares its borders with eight countries in Southern Africa. According to data obtained from the Ministry of Fisheries and Livestock, regulated trade in livestock and livestock products between Zambia and other countries in Southern Africa is high. However, the porous nature of Zambia's borders facilitates unregulated trade and migration of wildlife through regional corridors. Similarly, the complex and largely unregulated nature of most borders in Southern Africa implies that local disease outbreaks can have regional socio-economic consequences [24]. Transboundary animal diseases such as foot and mouth disease and African swine fever have been shown to spread across regional borders during disease outbreaks [24,25]. Equally, the absence of regional BT prevention and control 
strategies possess a risk for disease spread by regulated and unregulated trade and natural migration of wildlife through regional corridors.

As of January 2018, the total cattle, goat and sheep population in Zambia was estimated to be 7.5 million, of which, the small-scale or traditional sector accounted for $96 \%$ of the total population (https://www.zamstats.gov.zm). The majority of small-scale farmers in Zambia rear locally adapted indigenous cattle, goats and sheep. In spite of this, data from the Ministry of Fisheries and Livestock indicate that in the last decade, there has been a significant increase in importation of breeding stock such as cattle (dairy), goats and sheep. This has been a result of government efforts to diversify the economy to support agriculture. While diseases such as foot and mouth disease have drastically affected poor small-scale farmers who largely depend on livestock as a source of protein, income and draft power [26], the socio-economic effects of BT in Zambia are not understood, largely due to the lack of disease surveillance mechanisms. In this study, molecular and serological evidence of the presence of BT in Zambia is reported. The findings have implications for evidenced-based formulation of prevention and control strategies.

\section{Materials and Methods}

\subsection{Study Area}

The country-wide investigation into the epidemiology of BT was triggered by the unexpected detection of BTV nucleic acid in a blood-engorged Culex quinquefasciatus mosquito pool captured during routine surveillance for arboviruses in Zambia. We collected whole blood $(n=679)$ from domestic and wild ruminants between August 2018 and December 2019. Of these, 603 samples were collected from traditional cattle, sheep and goats in Southern, Western and Copperbelt provinces, while 76 samples were obtained from wildebeest at a private game ranch in Lusaka Province. Archived whole blood $(n=1674)$ collected from indigenous cattle and wild ruminants (i.e., buffalo, impala and hartebeest) between January 2016 and May 2018 were included in this study. Stored sera $(n=449)$ collected from traditional cattle in Lusaka and Central Province in March 2017 were used to screen for antibodies against BTV. In summary, a total of 2802 samples from 14 districts in nine of the 10 provinces of Zambia were analyzed (Figure 1 and Table 1). Ethical considerations; This study was commissioned and approved by the Ministry of Fisheries and Livestock of the Government of the Republic of Zambia (MFL/DVS/05-02-18). 
Table 1. Summary of blood and serum samples collected from domestic and wild ruminants in selected provinces Zambia.

\begin{tabular}{|c|c|c|c|c|c|}
\hline Province & District & Species & Blood $^{+}$ & Sera & Year (Season) \\
\hline Copperbelt & Mpongwe & Cattle & $100(10)$ & - & 2018 (Dry) \\
\hline Eastern & Lundazi & Cattle & $350(35)$ & - & 2018 (Wet) \\
\hline \multirow[t]{3}{*}{ Northern } & Mbala & Cattle & $200(20)$ & - & 2016 (Wet) \\
\hline & Kasama & Cattle & $243(25)$ & - & 2016 (Wet) \\
\hline & Mpika & Cattle & $200(20)$ & - & 2016 (Wet) \\
\hline North-Western $\ddagger$ & Ikelenge & Buffalo & $5(1)$ & - & 2017 (Dry) \\
\hline \multirow[t]{4}{*}{ Western } & Mongu & Cattle & $210(21)$ & - & 2018 (Dry) \\
\hline & & Goats & $84(9)$ & - & 2018 (Dry) \\
\hline & & Sheep & $6(1)$ & - & 2018 (Dry) \\
\hline & Senanga & Cattle & $350(35)$ & - & 2017 (Dry) \\
\hline \multirow[t]{4}{*}{ Southern } & Livingstone & Cattle & $104(11)$ & - & 2019 (Dry) \\
\hline & Livingstone & Goats & $99(10)$ & - & 2019 (Dry) \\
\hline & Livingstone & Buffalo & $11(5)$ & - & 2017 (Dry) \\
\hline & Namwala & Cattle & $188(19)$ & - & 2017 (Wet) \\
\hline \multirow[t]{2}{*}{ Kafue National Park } & Mumbwa & Impala & $98(21)$ & - & 2017 (Dry) \\
\hline & & Hartebeest & $29(8)$ & - & 2017 (Dry) \\
\hline Lusaka $\ddagger$ & Chongwe & Hartebeest & $76(8)$ & - & 2018 (Dry) \\
\hline \multirow[t]{3}{*}{ Central } & Shibuyunji & Cattle & & 110 & 2017 (Dry) \\
\hline & Mumbwa & Cattle & & 115 & 2017 (Wet) \\
\hline & Itezhi tezhi & Cattle & & 114 & 2017 (Wet) \\
\hline Lusaka & Chongwe & Cattle & & 110 & 2017 (Wet) \\
\hline Total & & & $2353(259)$ & 449 & \\
\hline
\end{tabular}

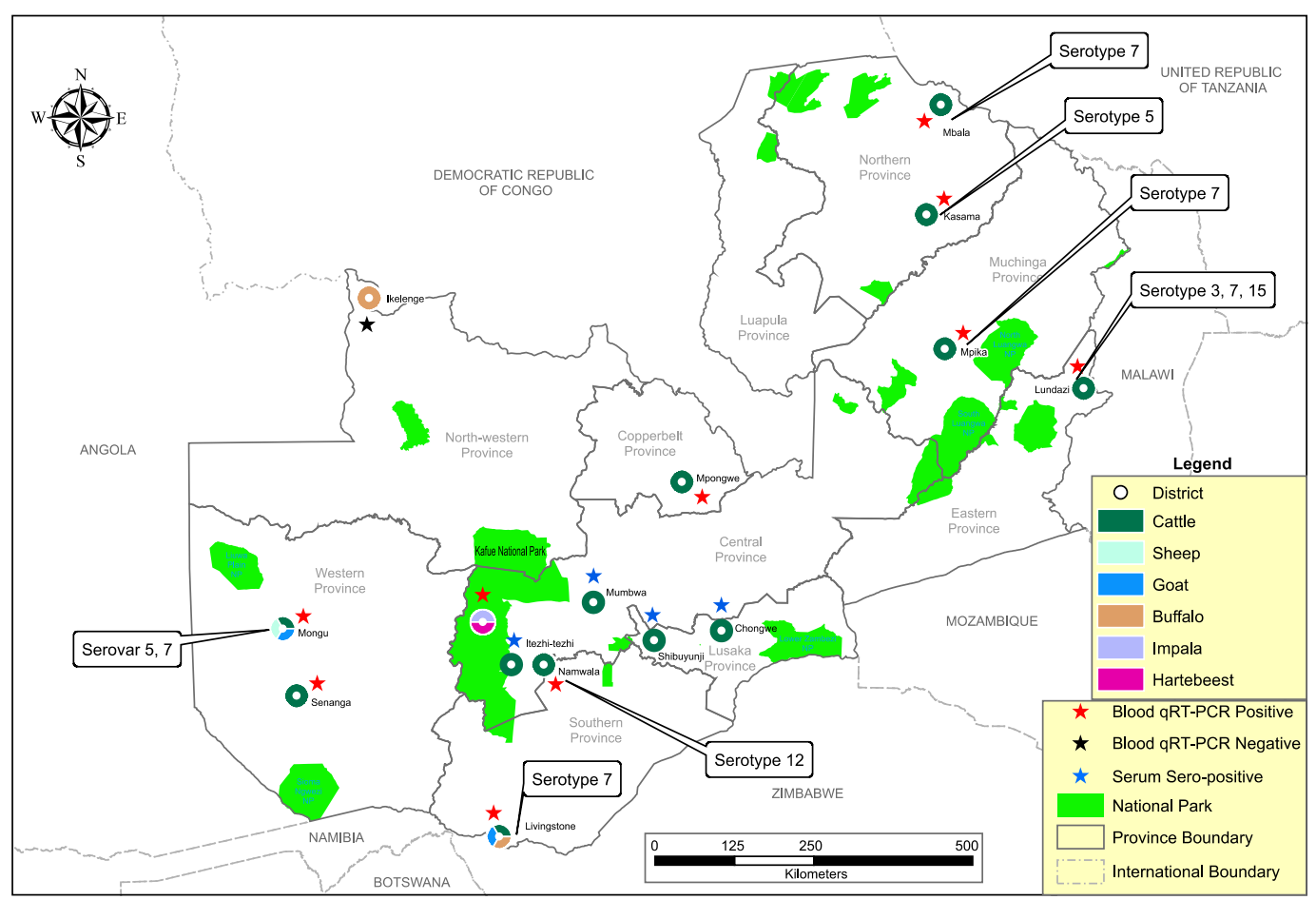

Figure 1. Map showing sample collection sites, bluetongue virus nucleic acid detection, antibody and serotyping results in selected districts and provinces of Zambia.

\subsection{Blood and Serum Samples}

Blood ( $n=2353$; Table 1$)$ was pooled $(n=259)$ as described previously [27] and total RNA was extracted using the QIAamp Viral RNA Mini Kit (https://www.qiagen.com) according to the manufacturer's protocol. Initial screening for BTV nucleic acid was conducted using a real-time reverse transcription (qRT-PCR) assay targeting segment 9 of BTV genome [28]. Samples with cycle 
threshold values below 39 were classified as positive based on parallel results obtained by the World Organisation for Animal Health (OIE) recommended nested RT-PCR assay (https://www.oie.int). In pools classed as positive by qRT-PCR, RNA was extracted from individual samples that constituted the pool and screening for BTV genome was conducted by qRT-PCR assay [28]. For serotype determination, a partial region of the segment 2 genome was amplified using PrimeScript One Step RT-PCR kit (Takara, Shiga, Japan) as previously described [29]. To amplify segment 10 gene which is used in topotype determination [14], primers (sense primer; 5'-ATGCTATCCGGGCTGATYC-3' and antisense primer; $5^{\prime}$-CCCGYTAKACACARCAGTRGG-3') were designed in Geneious software (https://www.geneious.com) and RT-PCR was performed using PrimeScrip One Step RT-PCR kit as previously described [30].

\subsection{Sequencing and Phylogenetic Analysis}

Sequence libraries for segments 2 and 10 were prepared using Illumina Nextera XT DNA Library Preparation Kit and sequenced on illumina Miseq (https://www.illumina.com). Raw reads were assembled de novo in Geneious software and phylogenetic analyses were implemented in MEGA 7 (https://www.megasoftware.net). Nucleotide sequences were deposited in the DDBJ GenBank under accession numbers LC569997-LC570005 and LC570261-LC570271.

\subsection{Serologic Analysis}

Cattle sera were analyzed for BTV antibodies using the ID Screen Bluetongue Competition ELISA assay (IDVet, Grabels, France), which is based on the VP7 protein of BTV as per manufacturer's instructions. Samples with a competition percentage $\geq 40 \%$ were considered negative while those $<40 \%$ were considered positive. Samples that gave inconclusive results were re-tested. Prevalence of BTV nucleic acid and antibodies were calculated using EpiTools epidemiological calculators (https://epitools.ausvet.com.au).

\section{Results}

\subsection{Molecular Screening and Phylogenetic Analysis}

Of the 259 pooled blood samples analyzed by qRT-PCR, 87 (33.6\%) were positive for BTV nucleic acid (Table 2). Overall, BTV nucleic acid was detected in domestic ruminants from all study sites (districts) in Eastern, Western, Southern, Northern, Muchinga and Copperbelt provinces, while only a single hartebeest pool from Kafue National Park in Central Province was positive among the wildlife samples (Figure 1 and Table 2). The overall estimated pooled prevalence of BTV nucleic acid was $4.4 \%$ (95\% CI (3.6-5.4)) (Table 3). Pooled prevalence in cattle was 4.8\% (95\% CI (3.8-6.0)), slightly lower than what was observed in goats $(7.2 \%, 95 \%$ CI (3.3-13.1)). In wildlife, pooled prevalence was $0.4 \%(95 \% \mathrm{CI}$ $(0.0-1.8))$, significantly lower $(p<0.001, \mathrm{OR}=0.04)$ than in cattle $(4.8 \%)$ and goats $(7.2 \%)$. Prevalence in the dry season $(2.2 \% ; 95 \%$ CI $(1.4-3.2))$ was significantly low $(p<0.0001, \mathrm{OR}=5.4)$ as compared to the wet season $(7.3 \%$; $95 \% \mathrm{CI}(5.6-9.3))$. In cattle and goats, the pooled prevalence for the dry season was $1.8 \%(95 \%$ CI (1.0-3.1)) and 2.7\% (95\% CI (1.7-4.0)), respectively. 
Table 2. Bluetongue virus nucleic acid detection results in pooled blood from domestic and wild ruminants in selected provinces of Zambia.

\begin{tabular}{cccccc}
\hline Province & District & Species & Pools Tested & qRT-PCR & Season \\
\hline Copperbelt & Mpongwe & Cattle & 10 & $1(10)$ & Dry \\
Eastern & Lundazi & Cattle & 35 & $16(45.7)$ & Wet \\
Northern & Mbala & Cattle & 20 & $16(80)$ & Wet \\
& Kasama & Cattle & 25 & $18(72)$ & Wet \\
& Mpika & Cattle & 20 & $11(55)$ & Wet \\
North-Western $\ddagger$ & Ikelenge & Buffalo & 1 & $0(0)$ & Dry \\
Western & Mongu & Cattle & 21 & $4(19)$ & Dry \\
& & Goats & 9 & $2(22.2)$ & Dry \\
& Senanga & Cattle & 1 & $0(0)$ & Dry \\
Southern & Livingstone & Cattle & 11 & $2(5.7)$ & Dry \\
& & Goats & 10 & $8(54.5)$ & Dry \\
Kafue National Park & Buffalo & 5 & $0(80)$ & Dry \\
& Namwala & Cattle & 19 & $2(10.5)$ & Dry \\
Lusaka $\ddagger$ & Impala & 21 & $0(0)$ & Wet \\
Total & Chongwe & Hartebeest & 8 & $1(12.5)$ & Dry \\
\end{tabular}

${ }^{\dagger}$ Positive (percent), ${ }^{\ddagger}$ private game ranch.

Table 3. Pooled prevalence of bluetongue virus nucleic acid during different seasons in domestic and wild ruminants from Zambia.

\begin{tabular}{cccc}
\hline Species & Sampling Season & Pools $^{\dagger}$ & Pooled Prevalence $\ddagger^{\dagger}$ \\
\hline Cattle, goats, buffalo, impala, hartebeest & Wet, Dry & $87 / 259(33.6)$ & $4.4(3.6-5.4)$ \\
Cattle, goats, buffalo, impala, hartebeest & Dry & $17 / 99(17.2)$ & $2.2(1.4-3.2)$ \\
Cattle & Wet and Dry & $76 / 196(38.8)$ & $4.8(3.8-6.0)$ \\
Cattle & Wet & $63 / 119(52.9)$ & $7.3(5.6-9.3)$ \\
Cattle & Dry & $13 / 77(16.9)$ & $1.8(1.0-3.1)$ \\
Goats & Wet & - & - \\
Goats & Dry & $10 / 19(52.6)$ & $7.2(3.3-13.1)$ \\
Cattle and Goats & Dry & $23 / 96(24.0)$ & $2.7(1.7-4.0)$ \\
Wildlife & Dry & $1 / 43(2.3)$ & $0.4 \%(0.0-1.8])$
\end{tabular}

${ }^{\dagger}$ Positive pools/total no. tested (\% positive), ${ }^{\ddagger}$ percent $(95 \% \mathrm{CI}) ; \%$, percent; CI, confidence interval.

On sequence analysis of segment 2, five different serotypes were identified (i.e., 3, 5, 7, 12 and 15) (Figure 1). Serotypes 5 and 7 were detected in Northern Province, while in Eastern Province, serotypes 3, 7 and 15 were identified. In Western Province, we detected serotypes 5 and 12, whereas in Southern Province, serotypes 7 and 12 were identified. Repeated attempts to identify circulating serotypes in other areas were unsuccessful. On BLAST search, serotype 7 viruses shared the highest nucleotide identity (93.4-95.1\%) with an isolate from South Africa (accession no. MN710210), while serotype 5 viruses from Kasama (KS08) and Mongu (ZG284) were similar to Nigerian (96.4\%; accession no. AJ585182) and Australian (92\%; accession no. MG924987) isolates, respectively. Serotype 3 viruses shared close similarity (98.2-99.4\%) to an isolate from South Africa (accession no. MG255540), while serotype 12 viruses from Namwala and Mongu were similar to isolates from South Africa (95.3\%; accession no. MG255670) and Israel (96.4\%; accession no. MN710208), respectively. Serotype 15 shared high similarity (98.3\%) with an isolate from Israel (accession no. KP821098). On segment 2 gene phylogeny, BT viruses clustered into 12 nucleotypes. BT viruses detected in this study clustered into five distinct nucleotypes (i.e., B, E, F, G and J) (Figure 2). In Northern Province, we found nucleotypes $\mathrm{E}$ and $\mathrm{F}$ while in Eastern Province, nucleotypes F, B, and J were identified. In Western and Southern Provinces, nucleotypes E, G and G, F were detected, respectively. 


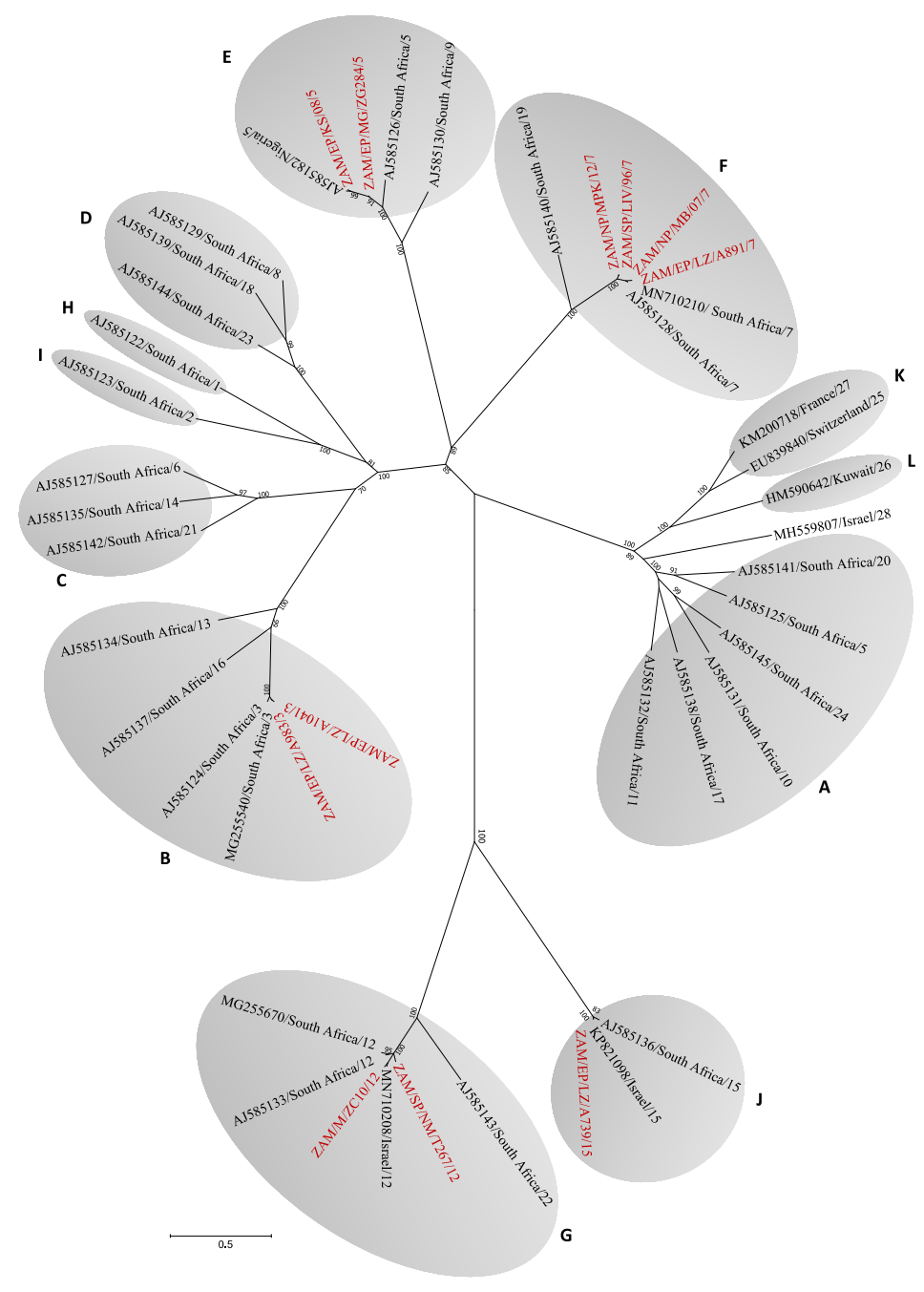

Figure 2. Phylogenetic tree of segment 2 gene of viruses detected in this study. The tree was generated using the Maximum Likelihood method based on the general time reversable (GTR) model with 1000 bootstrap replicates. Numbers at branch nodes indicate bootstrap values ( $>60 \%)$. Viruses characterized in the present study are in red text. Shaded area and letters represent BTV nucleotypes. References sequences for BTV1 to 28 are in black text. Bar-number of nucleotide substitutions per site. Abbreviations: EP, Eastern Province; SP, Southern Province; WP, Western Province; NP, Northern Province; LZ, Lundazi; MG, Mongu; LIV, Livingstone; NM, Namwala; MB, Mbala; KS, Kasama; MPK, Mpika.

On NS3 gene phylogeny, BTVs clustered into Western and Eastern topotypes (Figure 3). Topologically, viruses from this study formed three distinct clades within the Western topotypes. Clade A consisted of serotype 7, 12 and 15 from the Northern, Eastern and Western provinces and clustered with Western 2 topotypes from South Africa and Gibraltar. Clade B included serotypes 3, 5, 7 and 12 from the Northern, Southern and Eastern provinces that were closely related to Western 1 topotypes from South Africa. Interestingly, clade C contained serotypes 3 and 7 from the Eastern Province, which along with an isolate from Israel, showed a phylogenetic clustering pattern closely related to, but distinct from the Western 2 topotype. 


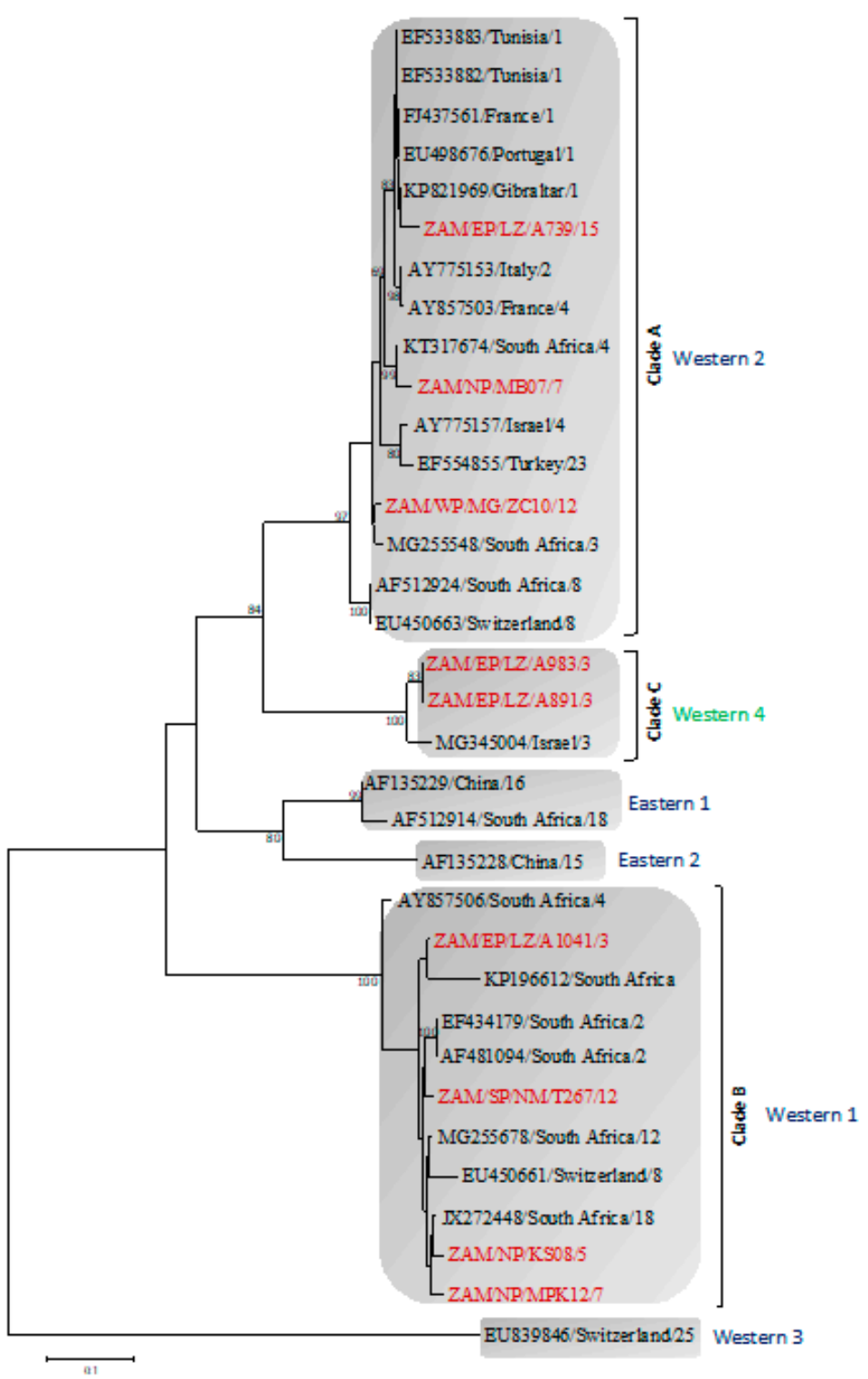

Figure 3. Phylogenetic tree of segment 10 gene of viruses detected in this study. The tree was generated using the Maximum Likelihood method based on the Tamura 3-parameter (T92) model with 1000 bootstrap replicates. Numbers at branch nodes indicate bootstrap values ( $>60 \%$ ). Viruses characterized in the present study are in red text. Novel topotype is in green text. Right brackets-clade. Shaded area-topotype. Reference sequences for Western and Eastern topotypes are in black text. Bar-number of nucleotide substitutions per site. Abbreviations: EP, Eastern Province; SP, Southern Province; WP, Western Province; NP, Northern Province; LZ, Lundazi; MG, Mongu; NM, Namwala; MB, Mbala; KS, Kasama; MPK, Mpika.

\subsection{BTV Antibodies in Cattle}

Antibodies against BTV were detected in 432 of 449 of the cattle tested by ELISA. Overall seroprevalence was high (96.2\%, 95\% CI (94.0-97.6)) for all study sites. In Chongwe District in Lusaka Province, 95.5\% (105/110) of the cattle tested were seropositive for antibodies against BTV (95\% CI, (89.8-98.0)). In Central Province, antibodies against BTV were detected in all the three study sites; Itezhi tezhi (92.1\%; 95\% CI (85.7-95.8)), Shibuyunji (98.2\%; 95\% CI (93.6-99.5)) and Mumbwa districts (99.1\%; 95\% CI (95.2-99.9)). 


\section{Discussion}

Although mosquitoes are not competent vectors for BTV, the incidental detection of BTV nucleic acid from a blood-engorged pool collected from Western Province of Zambia [31] supports the idea of a potential role of mosquitoes in the epidemiology of BT [32,33]. Detection of BTV nucleic acid and antibodies in indigenous cattle and goats in eight provinces (i.e., Eastern, Copperbelt, Southern, Northern, Muchinga, Western, and Lusaka and Central) indicates widespread distribution of BT in Zambia. There was a significant difference $(p<0.0001, \mathrm{OR}=5.4)$ in nucleic acid prevalence rates between the wet and dry season ( $7.3 \%$ vs. $2.2 \%$; Table 3$)$, which is likely attributable to increased vector activity in the wet season [33]. In addition, this finding suggests seasonal cyclicity of BT in Zambia. The prevalence of BTV nucleic acid observed in cattle and goats in both wet $(7.3 \%)$ and dry $(2.7 \%)$ seasons as compared to wildlife $(0.4 \%)$, suggests that cattle and goats, unlike wildlife, play an important role in the maintenance of BTV in Zambia. These results support earlier assertions that cattle and small ruminants such as goats, are important reservoir hosts for BTV in Africa [33-35].

Even though our results suggest a limited role of wild ruminants in the epidemiology of BT in Zambia, at the wildlife-livestock interface area, the role of wildlife in disease maintenance and transmission must not be overlooked. A previous study in Zambian wild ruminants demonstrated presence of antibodies against BTV [20]. Similarly, high prevalence of antibodies against BTV were demonstrated in wildlife in Zimbabwe (44.1\%; 353/800) and Botswana (71.5\%; 348/487) [36,37], intimating a wildlife role in the maintenance of BTV. To further clarify the role of wildlife in the epidemiology of BT in Zambia and the region, more studies will need to be conducted at the wildlife-livestock interface areas.

In this study, BTV nucleic acid in a local breed of sheep from Mongu District in Western Province was not detected, although goats from the same herd were positive for BTV nucleic acid. This was possibly due to virus clearance and/or lack of exposure to BTV prior to sampling. Notably, the farmer did not experience a disease in sheep with clinical signs similar to BT, probably due to the fact that indigenous local breeds, unlike exotic ones, are resistant to BT [38]. Still, this finding was intriguing as sheep are known to be generally more susceptible to BTV infection than goats [3].

Five different BTV serotypes were detected in cattle, that is 3, 5, 7, 12 and 15, while only serotype 5 was detected in goats. This heterogeneity of serotypes suggests that cattle, unlike goats, could be the main reservoir hosts for BTV in Zambia. Serotypes 3 and 15 detected in Eastern Province were previously reported in neighboring Malawi [19]. Similarly, in the segment 10 phylogeny (Figure 3), most viruses detected in this study were closely related to isolates from South Africa. This finding suggests possible transboundary exchange of viruses through legal and/or illegal trade of livestock. Accordingly, the detection of BTV nucleic acid and multiple circulating serotypes, particularly in regions bordering other countries (Figure 1), stresses the need for a regional effort in the control and prevention of BT. The identification of five different serotypes and three Western topotypes intimates a high genetic diversity among BTV in Zambia. Two viruses (i.e., ZAM/EP/LZ/A983/3 and ZAM/EP/LZ/A891/3) in clade C (Figure 3) clustered distinctly from the closely related Western 2 topotype. From a previously published report [14], close inspection of two nucleotide sequences from Eastern 1 topotype (accession no. AF135229) and Eastern 2 topotype (accession no. AF135228) revealed 87.3\% nucleotide similarity. A reference sequence from Western 2 topotype (accession no. EF554855) and the two viruses from this study in clade $C$ showed $85.9-86.1 \%$ nucleotide similarity. Based on this analogy, we propose this group to be a novel topotype and have thus designated it as Western 4 topotype.

The seroprevalence $(96.2 \%)$ of BTV in cattle from Lusaka and Central provinces was high, indicative of widespread exposure to infection. High seroprevalence $(95.9 \%)$ has been previously reported in cattle from Madagascar [35]. The observed high seroprevalence in cattle from Zambia was possibly due to increased Culicoides activity since sampling was undertaken during the wet season. This finding supports our results of high nucleic acid prevalence in the wet season (Table 2). Taken together, molecular and serologic results suggest possible BT endemicity in Zambia. The relatively low sheep population $(n=170,262)$ has likely contributed to the silent circulation of the 
virus. Nevertheless, the increased preference for BT-susceptible exotic breeds of sheep, goats and cattle during restocking may lead to the emergence of BT [3]. Recently, there has been a high demand for small ruminants in the region with other markets emerging in the Middle East. Most small- and large-scale farmers in Zambia have exploited the available regional markets for small ruminants. Furthermore, the transfrontier increase in movement of livestock that is driven by price differences, socio-cultural links, climate change, transhumance and nomadism [39], necessitates the need for regional BT prevention and control strategies that will mitigate potential socio-economic effects.

\section{Conclusions}

This study has demonstrated the presence of BTV nucleic acid and antibodies in domestic and wild ruminants in Zambia. Findings from this study have national and regional implications for the control and prevention of BT. It is anticipated that this work will not only improve the understanding of BT, but will also contribute to the formulation of evidence-based prevention and control strategy/policy in Zambia and the wider region.

Author Contributions: Conceptualization, H.M.C., M.S. (Michihito Sasaki), E.S., M.J.C., W.W.H., Y.O., and H.S., Funding acquisition, Y.S., P.F., Y.O., and H.S., Sampling, H.M.C., I.S., D.S., C.H.L., M.M., A.M., C.C., L.M., L.E.M., H.H., Y.Q., Y.E., H.S., Y.O., Analysis, H.M.C., M.S. (Michihito Sasaki), G.G., L.M., L.E.M., A.N.M., K.L.S., H.M.M., K.S.N., H.S., and Y.O. Supervision, M.S.(Martin Simuunza), E.S., Y.O., and H.S. All authors have read and agreed to the published version of the manuscript.

Funding: This study was supported in part by; The Japan Agency for Medical Research and Development (AMED) (JP19fm0108008, JP20wm0125008); AMED/Japan International Cooperation Agency (JICA) within the framework of the Science and Technology Research Partnership for Sustainable Development (SATREPS; JP19jm0108008)); Grants-in-Aid for Scientific Research on Innovative Areas from the Ministry of Education, Culture, Sports, Science and Technology (MEXT) of Japan (16H06429, 16H06431, 16K21723); Department of Veterinary Services in the Ministry of Fisheries and Livestock of the Republic of Zambia.

Acknowledgments: We are greatful to Moonga Ladslav, Evans Mulenga, Penjani Kapila, Joseph Ndebe, and the district veterinary officers in the Ministry of Fisheries and Livestock.

Conflicts of Interest: The funders had no role in the design of the study; in the collection, analyses, or interpretation of data; in the writing of the manuscript, or in the decision to publish the results. The authors declare no conflict of interest.

\section{References}

1. Meyer, G.; Lacroux, C.; Léger, S.; Top, S.; Goyeau, K.; Deplanche, M.; Lemaire, M. Lethal bluetongue virus serotype 1 infection in llamas. Emerg. Infect. Dis. 2009, 15, 608-610. [CrossRef]

2. Alexander, K.A.; MacLachlan, N.J.; Kat, P.W.; House, C.; O’Brien, S.J.; Lerche, N.W.; Sawyer, M.; Frank, L.G.; Holekamp, K.; Smale, L. Evidence of natural bluetongue virus infection among African carnivores. Am. J. Trop. Med. Hyg. 1994, 51, 568-576. [CrossRef]

3. Erasmus, B.J. Bluetongue virus. Virus Infect. Ruminants 1990, 3, $227-237$.

4. Conraths, F.J.; Gethmann, J.M.; Staubach, C.; Mettenleiter, T.C.; Beer, M.; Hoffmann, B. Epidemiology of bluetongue virus serotype 8, Germany. Emerg. Infect. Dis. 2009, 15, 433-435. [CrossRef] 
5. Darpel, K.E.; Batten, C.A.; Veronesi, E.; Shaw, A.E.; Anthony, S.; Bachanek-Bankowska, K.; Kgosana, L.; bin-Tarif, A.; Carpenter, S.; Müller-Doblies, U.U.; et al. Clinical signs and pathology shown by British sheep and cattle infected with bluetongue virus serotype 8 derived from the 2006 outbreak in northern Europe. Vet. Rec. 2007, 161, 253-261. [CrossRef]

6. Singer, R.S.; MacLachlan, N.J.; Carpenter, T.E. Maximal predicted duration of viremia in bluetongue virus-infected cattle. J. Vet. Diagnostic. Investig. 2001, 13, 43-49. [CrossRef] [PubMed]

7. Huismans, H.; Erasmus, B.J. Identification of the serotype-specific and group-specific antigens of bluetongue virus. Onderstepoort J. Vet. Res. 1981, 48, 51-58.

8. Ratinier, M.; Caporale, M.; Golder, M.; Franzoni, G.; Allan, K.; Nunes, S.F.; Armezzani, A.; Bayoumy, A.; Rixon, F.; Shaw, A.; et al. Identification and characterization of a novel non-structural protein of bluetongue virus. PLoS Pathog. 2011, 7, e1002477. [CrossRef]

9. Belhouchet, M.; Mohd Jaafar, F.; Firth, A.E.; Grimes, J.M.; Mertens, P.P.C.; Attoui, H. Detection of a fourth orbivirus non-structural protein. PLoS ONE 2011, 6, e25697. [CrossRef] [PubMed]

10. Maan, S.; Maan, N.S.; Samuel, A.R.; Rao, S.; Attoui, H.; Mertens, P.P.C. Analysis and phylogenetic comparisons of full-length VP2 genes of the 24 bluetongue virus serotypes. J. Gen. Virol. 2007, 88, 621-630. [CrossRef] [PubMed]

11. Kahlon, J.; Sugiyama, K.; Roy, P. Molecular basis of bluetongue virus neutralization. J. Virol. 1983, 48, 627-632. [CrossRef] [PubMed]

12. Bumbarov, V.; Golender, N.; Jenckel, M.; Wernike, K.; Beer, M.; Khinich, E.; Zalesky, O.; Erster, O. Characterization of bluetongue virus serotype 28. Transbound. Emerg. Dis. 2020, 67, 171-182. [CrossRef] [PubMed]

13. Schulz, C.; Bréard, E.; Sailleau, C.; Jenckel, M.; Viarouge, C.; Vitour, D.; Palmarini, M.; Gallois, M.; Höper, D.; Hoffmann, B.; et al. Bluetongue virus serotype 27: Detection and characterization of two novel variants in Corsica, France. J. Gen. Virol. 2016, 97, 2073-2083. [CrossRef] [PubMed]

14. Maan, S.; Maan, N.S.; van Rijn, P.A.; van Gennip, R.G.P.; Sanders, A.; Wright, I.M.; Batten, C.; Hoffmann, B.; Eschbaumer, M.; Oura, C.A.L.; et al. Full genome characterisation of bluetongue virus serotype 6 from the Netherlands 2008 and comparison to other field and vaccine strains. PLoS ONE 2010, 5, e10323. [CrossRef] [PubMed]

15. Maan, S.; Maan, N.S.; Nomikou, K.; Veronesi, E.; Bachanek-Bankowska, K.; Belaganahalli, M.N.; Attoui, H.; Mertens, P.P.C. Complete genome characterisation of a novel 26th bluetongue virus serotype from Kuwait. PLoS ONE 2011, 6, e26147. [CrossRef]

16. Mellor, P.S. The replication of bluetongue virus in Culicoides vectors. Curr. Top. Microbiol. Immunol. 1990, 162, 143-161. [CrossRef] [PubMed]

17. Venter, G.J.; Paweska, J.T.; Van Dijk, A.A.; Mellor, P.S.; Tabachnick, W.J. Vector competence of Culicoides bolitinos and C. imicola for South African bluetongue virus serotypes 1, 3 and 4. Med. Vet. Entomol. 1998, 12, 378-385. [CrossRef]

18. Coetzee, P.; Stokstad, M.; Venter, E.H.; Myrmel, M.; Van Vuuren, M. Bluetongue: A historical and epidemiological perspective with the emphasis on South Africa. Virol. J. 2012, 9, 198. [CrossRef]

19. Haresnape, J.M.; Taylor, W.P.; Lungu, S.A. The epidemiology of bluetongue in Malawi. Epidemiol. Infect. 1988, 100, 493-499. [CrossRef]

20. Krauss, H.; Roettcher, D.; Weiss, R.; Danner, K.; Hubschle, O.J.B. Wildtiere als Infectionpotential für Nutztiere: Untersuchungen an Wild in Sambia. Giessener Beitrage zur Entwicklungsforschung. R. I 1984, 10, 133-149.

21. Mweene, A.S.; Pandey, G.S.; Sinyangwe, P.; Nambota, A.; Samui, K.; Kida, H. Viral diseases of livestock in Zambia. Jpn. J. Vet. Res. 1996, 44, 89-105. [PubMed]

22. Ghirotti, M.; Semproni, G.; De Meneghi, D.; Mungaba, F.N.; Nannini, D.; Calzetta, G.; Paganico, G. Sero-prevalences of selected cattle diseases in the Kafue flats of Zambia. Vet. Res. Commun. 1991, 15, 25-36. [CrossRef] [PubMed]

23. Kitaoka, S.; Zulu, F.P. Species composition of Culicoides (Diptera: Ceratopogonidae) found at Chilanga near Lusaka, Zambia. Niigata Sangyo Univ. Bull. 1990, 4, 197-206.

24. Calkins, C.M.; Scasta, J.D. Transboundary Animal Diseases (TADs) affecting domestic and wild African ungulates: African swine fever, foot and mouth disease, Rift Valley fever (1996-2018). Res. Vet. Sci. 2020, 131, 69-77. [CrossRef] [PubMed] 
25. Simulundu, E.; Chambaro, H.M.; Sinkala, Y.; Kajihara, M.; Ogawa, H.; Mori, A.; Ndebe, J.; Dautu, G.; Mataa, L.; Lubaba, C.H.; et al. Co-circulation of multiple genotypes of African swine fever viruses among domestic pigs in Zambia (2013-2015). Transbound. Emerg. Dis. 2018, 65, 114-122. [CrossRef]

26. Sinkala, Y.; Simuunza, M.; Muma, J.B.; Pfeiffer, D.U.; Kasanga, C.J.; Mweene, A. Foot and mouth disease in Zambia: Spatial and temporal distributions of outbreaks, assessment of clusters and implications for control. Onderstepoort J. Vet. Res. 2014, 81, E1-E6. [CrossRef]

27. Flannery, J.; Rajko-Nenow, P.; Hicks, H.; Hill, H.; Gubbins, S.; Batten, C. Evaluating the most appropriate pooling ratio for EDTA blood samples to detect Bluetongue virus using real-time RT-PCR. Vet. Microbiol. 2018, 217, 58-63. [CrossRef]

28. Maan, N.S.; Maan, S.; Belaganahalli, M.; Pullinger, G.; Montes, A.J.A.; Gasparini, M.R.; Guimera, M.; Nomikou, K.; Mertens, P.P.C. A quantitative real-time reverse transcription PCR (qRT-PCR) assay to detect genome segment 9 of all 26 bluetongue virus serotypes. J. Virol. Methods 2015, 213, 118-126. [CrossRef]

29. Maan, N.S.; Maan, S.; Belaganahalli, M.N.; Ostlund, E.N.; Johnson, D.J.; Nomikou, K.; Mertens, P.P.C. Identification and differentiation of the twenty six bluetongue virus serotypes by RT-PCR amplification of the serotype-specific genome segment 2. PLoS ONE 2012, 7, e32601. [CrossRef]

30. Steyn, J.; Venter, E.H. Sequence analysis and evaluation of the NS3/A gene region of bluetongue virus isolates from South Africa. Arch. Virol. 2016, 161, 947-957. [CrossRef]

31. Orba, Y.; Hang'ombe, B.M.; Mweene, A.S.; Wada, Y.; Anindita, P.D.; Phongphaew, W.; Qiu, Y.; Kajihara, M.; Mori-Kajihara, A.; Eto, Y.; et al. First isolation of West Nile virus in Zambia from mosquitoes. Transbound. Emerg. Dis. 2018, 65, 933-938. [CrossRef] [PubMed]

32. Brown, S.E.; Gorman, B.M.; Tesh, R.B.; Knudson, D.L. Isolation of bluetongue and epizootic hemorrhagic disease viruses from mosquitoes collected in Indonesia. Vet. Microbiol. 1992, 32, 241-252. [CrossRef]

33. Gerdes, G.H. A South African overview of the virus, vectors, surveillance and unique features of bluetongue. Vet. Ital. 2004, 40, 39-42.

34. Toye, P.; Batten, C.; Kiara, H.; Henstock, M.; Edwards, L.; Thumbi, S.; Poole, E.J.; Handel, I.; Bronsvoort, B.D.C.; Hanotte, O.; et al. Bluetongue and Epizootic Haemorrhagic Disease virus in local breeds of cattle in Kenya. Res. Veter-Sci. 2013, 94, 769-773. [CrossRef]

35. Andriamandimby, S.F.; Viarouge, C.; Ravalohery, J.-P.; Reynes, J.-M.; Sailleau, C.; Tantely, M.L.; Elissa, N.; Cardinale, E.; Sall, A.A.; Zientara, S.; et al. Detection in and circulation of Bluetongue virus among domestic ruminants in Madagascar. Vet. Microbiol. 2015, 176, 268-273. [CrossRef] [PubMed]

36. Anderson, E.C.; Rowe, L.W. The prevalence of antibody to the viruses of bovine virus diarrhoea, bovine herpes virus 1, rift valley fever, ephemeral fever and bluetongue and to Leptospira sp in free-ranging wildlife in Zimbabwe. Epidemiol. Infect. 1998, 121, 441-449. [CrossRef]

37. Simpson, V.R. Serological evidence of bluetongue in game animals in Botswana. Trop. Anim. Health Prod. 1978, 10, 55-60. [CrossRef]

38. Fernández-Pacheco, P.; Fernández-Pinero, J.; Agüero, M.; Jiménez-Clavero, M.A. Bluetongue virus serotype 1 in wild mouflons in Spain. Vet. Rec. 2008, 162, 659-660. [CrossRef]

39. Maree, F.F.; Kasanga, C.J.; Scott, K.A.; Opperman, P.A.; Melanie, C.; Sangula, A.K.; Raphael, S.; Yona, S.; Wambura, P.N.; King, D.P.; et al. Challenges and prospects for the control of foot-and-mouth disease: An African perspective. Veter Med. Res. Rep. 2014, 5, 119-138. [CrossRef]

(C) 2020 by the authors. Licensee MDPI, Basel, Switzerland. This article is an open access article distributed under the terms and conditions of the Creative Commons Attribution (CC BY) license (http://creativecommons.org/licenses/by/4.0/). 